\title{
O governo brasileiro e o risco de uma democracia simbólica
}

\section{Vanessa Santana de Jesus Souza}

RESUMO: $O$ presente artigo propõe uma análise do risco de a democracia brasileira ser reduzida ao simbolismo, diante do crescimento do discurso autoritário, no cenário político do país, na atualidade. Utiliza--se o método lógico indutivo, com revisão bibliográfica e apreciação crítica. Ao final, se propõe que a vigilância da eficácia social da democracia decorra da própria ação popular de defesa da titularidade e posse de sua soberania.

PALAVRAS-CHAVE: Democracia participativa. Democracia simbólica. Autoritarismo.

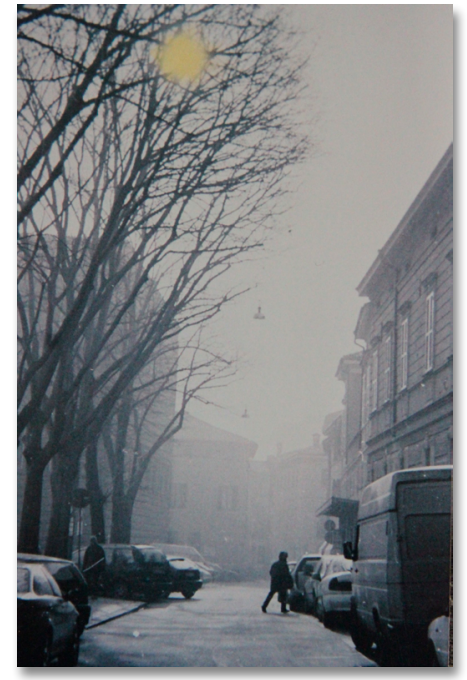

\section{Brazilian government and the risk of a symbolic democracy}

\section{Vanessa Santana de Jesus Souza}

Mestranda em Direito pela Universidade Federal da Bahia (UFBA). Bacharela em Direito pela Faculdade de Direito da UFBA. Advogada e conciliadora no Tribunal de Justiça do Estado da Bahia.

E-mail: vanessasjsouza@gmail.com
ABSTRACT: This article proposes an analysis of the risk of Brazilian democracy being reduced to symbolism in view of the growth of authoritarian discourse in the country's political scenario today. The inductive logical method was used, with bibliographic review and critical appraisal. In the end, it was proposed that the surveillance of the social effectiveness of democracy stems from the very popular action to defend the ownership and possession of its sovereignty.

KEYWORDS:

democracy. Symbolic democracy. Authoritarianism.

RECEBIDO: 03/08/2019

APROVADO: $10 / 01 / 2020$ 


\section{Introdução}

A evolução do conceito de democracia enquanto regime de governo ou forma de atribuição e gestão do poder político desenvolveu-se em conjunto com as concepções de Estado, soberania e cidadania. Da democracia direta da Antiguidade grega, cuja cidadania era restrita a um pequeno segmento da sociedade, passando pelo modelo representativo, cujo papel é a conciliação com o ideal individualista do liberalismo econômico, a democracia alcança a forma participativa, ampliativa da influência direta do povo na atuação dos poderes estatais e para a qual a informática e a internet têm gerado múltiplas possibilidades.

No entanto, a história da humanidade mostra que a democracia tende a se apresentar em ondas, as quais são seguidas de severos recuos ou avanços autoritários, o que se verificou tanto no mundo ocidental como um todo, quanto especificamente no Brasil. Tanto no exterior quanto em território brasileiro, a democracia assegurada constitucionalmente foi silenciosamente desgastada por forças políticas, econômicas e sociais, até ruir completamente mediante a quebra da ordem constitucional.

Considerando a crise ética, política e econômica pela qual o Brasil atravessa e que terminou por fortalecer o discurso autoritário no seio da sociedade, com repercussão direta na eleição do ultraconservador Jair Messias Bolsonaro para o cargo de Presidente da República, o presente artigo objetiva aventar o risco de perda da eficácia social da democracia participativa. Dessa forma, propõe-se o debate social acerca da democracia, evitando que ela se torne um mero símbolo destituído de mecanismos de efetivação, uma vez que o povo é o titular da soberania e, portanto, deve defender o seu exercício pleno.

\section{A democracia da Antiguidade à pós-modernidade}

O conceito clássico de democracia surgiu na Antiguidade grega, cujo maior expoente foi o filósofo Aristóteles, concebendo uma classificação de regimes de governo segundo o número de titulares do poder soberano. Aristóteles identificou três modelos puros de atribuição do poder político - monarquia, aristocracia e 
democracia -, assumindo, ainda, a possibilidade de esses modelos se degenerarem, respectivamente, em tirania, oligarquia e demagogia (BONAVIDES, 2000).

A democracia ateniense atribuía a soberania estatal ao povo, que a exercia diretamente, cuidando os cidadãos de governar soberanamente e de forma imediata o Estado, através de assembleias realizadas na sede do governo, sem a necessidade de eleição de representantes. A par da discussão acerca da diminuta parcela da população a quem era atribuída a qualidade de cidadãos (uma vez que mulheres, artesãos, comerciantes e escravos ficavam à margem da esfera político-democrática), na civilização ateniense, os homens livres participavam diretamente da gestão da coisa pública, em grupos de trabalho que, de forma rotativa, produziam leis, aplicavam-nas no cotidiano do Estado e decidiam controvérsias envolvendo seus pares (CABRAL NETO, 1997).

O segundo grande momento da democracia e do exercício da cidadania decorreu da conformação do Estado liberal, após a Revolução Francesa e a Independência dos Estados Unidos, com a Declaração do Bom Povo de Virgínia (1776), a Constituição dos Estados Unidos (1787), a Declaração dos Direitos do Homem e do Cidadão (1789) e a Constituição Francesa (1791). Nesse contexto, a teoria do contrato social de Thomas Hobbes foi substituída pelas teorias contratualistas de John Locke e Jean-Jacques Rousseau, para as quais os homens abdicam do estado de natureza por um contrato de colaboração, não de submissão, visando conciliar interesses sociais em prol de uma convivência harmônica que lhes proporcionasse uma garantia de suas liberdades individuais. Desse modo, os Estados liberais reconhecem as liberdades civis do cidadão, bem como a soberania popular, porém estabelecendo uma participação indireta dos cidadãos nas decisões de Estado (SANTOS, 2002a).

Cunhou-se o Estado Democrático de Direito e a democracia representativa, atribuindo a qualidade de cidadãos a uma parcela da população a quem se reconhece a prerrogativa de eleger os representantes do povo, os quais serão os responsáveis pelas decisões políticas e a gestão do Estado. Nessa conformação de Estado, pautado no liberalismo socioeconômico e no individualismo, as 
decisões políticas fundamentais, bem como os direitos e as liberdades individuais se encontram garantidos em um documento formal, a Constituição, cujas normas servem de moldura para a ação dos representantes eleitos. Em contrapartida, uma vez eleitos, os representantes do povo se conduziriam na vida pública, pelo menos em tese, em prol do interesse do projeto de Estado adotado, dissociando-se dos interesses particulares dos cidadãos.

No que concerne ao exercício da cidadania no Estado democrático liberal, bem observa José Afonso da Silva (1999) a cisão, realizada naquele contexto, entre o conceito de "homem" e de "cidadão", Conforme demonstrado pela Declaração dos Direitos do Homem e do Cidadão, proclamada pela França burguesa em 1789, e segundo a qual os direitos do homem estariam delimitados em direitos individuais de proteção contra o Estado, ao passo que os direitos do cidadão se restringiriam ao direito de votar e ser votado, ínsitos a uma democracia representativa, o resultado é uma ideologia individualista que prega que o cidadão, porque titular da soberania através unicamente do voto, se libertou da condição de súdito (SILVA, 1999).

Segundo Joseph Schumpeter, conquanto seja a democracia desejável como forma de governo, tendo se tornado a forma padrão de organização do poder político no mundo ocidental, a restrição sobre as formas de participação e soberania nas sociedades se justificariam pela necessidade de consenso acerca de um procedimento eleitoral para a formação dos governos, baseado na competição, restando ao povo eleger o melhor representante dentro um grupo restrito de capacitados. Aliado a isso, a teoria elitista de Schumpeter fundava-se na afirmação de que o povo não possui competência ou interesse político para participar ativamente da gestão do Estado, a chamada doutrina da apatia política (SANTOS, 2002b).

Em uma análise crítica, porém, cumpre lembrar que, inicialmente, o liberalismo econômico, que respaldou a ascensão da democracia no campo político, não se fundamentou na igualdade material, mas sim na igualdade meramente formal. O pensamento liberal se utiliza das demandas democráticas para garantir o direito de propriedade, circundando toda a filosofia econômica, 
jurídica e política em torno da propriedade privada. A democracia dos tempos modernos subordina a condição de cidadão à propriedade privada, tanto que o sufrágio universal, na maior parte da Europa ocidental no século XIX, era restrito aos homens detentores de propriedade ou pagadores de certo percentual de impostos, sendo o voto universal masculino um direito conquistado apenas entre meados do século XIX e inícios do século XX, enquanto o voto feminino demorou mais de meio século para ser conquistado de forma consistente. No Brasil, o voto feminino foi concedido em 1932, através do Decreto n 21.076, o Código Eleitoral Brasileiro, e posteriormente previsto na Constituição de 1934 (TOSI, 2016).

Essa visão tem como desdobramento uma perspectiva restrita de democracia, ou seja, a democracia que está na base do pensamento liberal é, na verdade, a democracia dos proprietários, tratando-se de um pensamento elitista. Isso fortalece a teoria da democracia representativa, mais oligárquica do que popular, porém é capaz de conciliar as demandas econômicas e democráticas ao redor do individualismo, da igualdade formal e das liberdades públicas (CABRAL NETO, 1997).

De acordo com a teoria de Samuel Huntington (1994) acerca da existência de ondas democráticas na história política mundial, desde o século XIX, os Estados passam por processos pendulares de reforma política, ora se instaurando a democratização, ora o autoritarismo, sendo possível identificar tendências mundiais. A primeira onda de democratização teria sido entre 1828 e 1926, a qual correspondeu à adoção do Estado Democrático de Direito, pautado pelo liberalismo econômico, pelo individualismo, pela igualdade formal e pela democracia representativa. Contudo, a incapacidade de a igualdade formal garantir a diminuição das desigualdades sociais, além do cenário de crise econômica, alimentou uma onda contrária, ou onda autoritária, entre 1922 e 1942, a exemplo do nazismo, na Alemanha, e do fascismo, na Itália, culminando na $2^{\text {a }}$ Guerra Mundial.

Já a segunda onda de democratização teria se iniciado após a $2^{a}$ Guerra Mundial e transcorrido no curto período entre 1943 e 1962. Do mesmo modo que a primeira onda, esta foi seguida de um período de autoritarismo, entre 1958 e 1975, abrangendo o 
período da Guerra Fria e da ditadura militar brasileira, e corresponde ao desenvolvimento do chamado Estado Social Democrático, ou Estado Constitucional Democrático, na mesma medida em que o Estado liberal foi dando lugar ao Estado de bem-estar social (HUNTINGTON, 1994).

Conforme defende Fábio Konder Comparato (1993), com a conformação das sociedades de massas e o agravamento do subdesenvolvimento econômico e social crônicos, a cidadania liberal-individualista resultou insuficiente e insatisfatória, precisando evoluir para outra forma de cidadania que contemplasse necessidades coletivas. Tratou-se, portanto, de uma superação com a conservação de seus elementos positivos, sem que houvesse a negação pura e simples da lógica anterior.

Segundo Boaventura de Sousa Santos (2002a), o consenso liberal - fundamentado na liberalização do mercado global, no afastamento do Estado da regulação econômico-social, na concepção minimalista da democracia e na concepção privatista do Direito e da Justiça - agravou as desigualdades sociais de forma tal que promoveu o retorno de grupos sociais marginalizados ao estado de natureza, uma vez que foram excluídos do contrato social. Nesse cenário, o Estado não alcança os grupos à margem da sociedade, não lhes oferecendo condições para o exercício de seus direitos fundamentais.

Em contrapartida, com as sociedades de massas, surge a demanda pela proteção de direitos coletivos em sentido amplo, os quais fogem da lógica individualista da proteção de direitos adotada pelo Estado liberal, a exemplo do direito de toda a humanidade a um meio ambiente equilibrado. Despontou, assim, a necessidade de evolução da concepção de Estado liberal para o Estado garantidor do bem-estar social. O Estado, então, passou à função de gestor da economia e da sociedade, e as Constituições passam a assegurar direitos sociais e transindividuais, sendo um marco histórico desse movimento as Constituições do México (1917) e de Weimar (1919), com repercussão no Brasil observada na Constituição de 1934.

Para Noberto Bobbio (1987), a solução para a crise da ineficácia dos direitos previstos no Estado liberal não passa pela alternância 
entre democracia representativa e democracia direta, mas sim por uma terceira via, intermediária, que considere a articulação dos avanços da democracia política com a criação de condições mínimas de bem-estar para as grandes massas da população. Segundo Bobbio (1987), atualmente o desenvolvimento da democracia consiste não na substituição da democracia representativa pela democracia direta, mas na passagem da democracia da esfera política para a esfera social.

Por consequência desse cenário, a democracia representativa se tornou insuficiente por não mais responder às demandas da sociedade. Assim, a lógica individual da representação política não mais se coaduna com a situação de exclusão dos setores marginalizados, nem mesmo com as demandas de natureza coletivas e difusas. Entrementes, a democracia direta parece impossível. Como síntese para a resposta dessa crise, começa a se formar o conceito de democracia participativa, mantendo características da forma semidireta, por não excluir a representatividade, porém aproximando os representados do contexto político, através da participação da sociedade civil nas decisões estratégicas do Estado. Paulo Bonavides (2001) aponta a democracia participativa como um direito fundamental de $4^{a}$ geração e conclui que a tecnologia é o elemento catalisador capaz de aproximar, cada vez mais, o povo das decisões políticas, fazendo com que a representatividade se torne uma parcela pequena do exercício da soberania popular, que passará a atuar cada vez mais diretamente, através de ferramentas online de integração da vontade dos cidadãos aos processos de gestão do Estado.

\section{A democracia no contexto brasileiro}

Assim como ocorreu com os países ocidentais em geral, a evolução constitucional brasileira, desde o Império, foi composta por ondas democráticas seguidas por recuos autoritários, instaurados devido a crises, tensões políticas, insurgências e rupturas (BONAVIDES, 2001).

Apesar da tendência liberal e até mesmo revolucionária da Assembleia Constituinte convocada em 1822, antes mesmo da 
proclamação da Independência, para a elaboração da primeira Constituição do Brasil, a imposição de um governo monárquico culminou na dissolução da Constituinte e na outorga da primeira Carta Magna do país, em 1824. A Constituição Imperial estabeleceu um governo monárquico hereditário, constitucional e representativo, prevendo 4 poderes: o legislativo, o judiciário, o executivo e o moderador, os últimos dois exercidos pelo imperador.

Contudo, a extensão do território brasileiro favorecia o fortalecimento de poderes locais, com grande autonomia, o que encorajou ideais descentralizadores, como a concepção de República e de democracia representativa - embasadas nas Constituições norte-americana, de 1787, e francesa, de 1791. O período imperial foi, portanto, um momento de eclosão de revoltas populares, como a Balaiada, ocorrida entre 1838 e 1841, no Maranhão; a Cabanada, ocorrida entre 1832 e 1835, de Pernambuco até o Pará; e a Sabinada, ocorrida entre 1837 e 1838, na Bahia (CUNHA JÚNIOR, 2015).

A primeira Constituição democrática brasileira foi promulgada em 1891 e trouxe, em seu preâmbulo, a declaração de que os representantes do povo brasileiro, reunidos em Congresso Constituinte, estabeleceram um regime livre e democrático na forma daquela Constituição da República dos Estados Unidos do Brasil. O seu artigo 15 apresentou como órgãos da soberania nacional os poderes legislativo, executivo e judiciário, harmônicos e independentes entre si. Adotou, destarte, como forma de governo, a República federativa, sob o regime democrático, representativo e através do sistema de separação tripartite dos poderes. A soberania popular, no entanto, era exercida através do voto universal masculino, cuja maioridade e capacidade eleitoral era atingida aos 21 anos, sendo excluídos a mulher, o mendigo, o analfabeto, os praças e os religiosos ordenados. A Constituição de 1891 foi notadamente marcada pela concepção de Estado liberal, protegendo os direitos civis e políticos, bem como prevendo expressamente o habeas corpus como garantia à liberdade de locomoção, através de uma declaração de direitos estabelecida em seu artigo 72 (BRASIL, 1891).

A Constituição de 1934 adveio da ruptura com a ordem constitucional anterior - denominada de Velha República - através de 
uma revolução nacional que culminou na assunção ao poder de Getúlio Vargas. Tal Constituição representou a consolidação do regime democrático, propondo-se a assegurar à nação a unidade, a liberdade, a justiça e o bem-estar social e econômico. Ela tratou pela primeira vez de direitos fundamentais de segunda geração, ou direitos sociais, sob influência da Constituição de Weimar, da Alemanha de 1919, fundando, assim, o Estado brasileiro de bem-estar social. Foi também a primeira Constituição ao prever o voto universal feminino, já autorizado de forma restrita através de decreto presidencial em 1932 (TOSI, 2016).

Contudo, a tendência autoritária de Getúlio Vargas e a instabilidade política decorrente do conflito entre ideais liberais e comunistas resultaram na instauração, pelo então presidente da República, de uma ditadura: o Estado Novo. Foi, então, outorgada a Constituição de 1937, autoritária, apelidada de "polaca" por ter forte influência da constituição fascista polonesa, extirpando do texto constitucional o ideal democrático. O objetivo maior da Constituição de 1937, ao declarar estado de emergência sob alegada ameaça comunista, foi fortalecer o poder executivo, através da extinção dos partidos políticos, da forte influência do poder legislativo (art. 39) e de prerrogativas como a dissolução da Câmara dos Deputados (art. 75, "b"). Nela, houve também a revisão de decisões do poder judiciário acerca da inconstitucionalidade de lei (art. 96, parágrafo único) (BRASIL, 1937).

A redemocratização se deu após o fim da $2^{a}$ Guerra Mundial, com a convocação de eleições presidenciais no Brasil de 1945, bem como com a promulgação da Constituição de 1946, de teor fortemente democrático e social, evidentemente baseada na Constituição de 1934 (CUNHA JÚNIOR, 2015). Assim, ela trouxe o preâmbulo de que os representantes do povo brasileiro se reunissem, sob a proteção de Deus, em Assembleia Constituinte, para organizar um regime democrático, através da promulgação da Constituição dos Estados Unidos do Brasil de 1946. Em seu artigo $1^{\circ}$, assegurou a forma federativa de Estado, o governo republicano e o sistema democrático representativo, este confirmado sob a declaração solene de que "todo poder emana do povo e em seu nome será exercido". Em sua carta de direitos e garantias 
individuais, o artigo 141 garantiu o pluripartidarismo, porém com proibição de partidos ou associações cujo programa contrariasse o regime democrático (BRASIL, 1946).

O restabelecimento da democracia durou aproximadamente 18 anos, sendo dissolvida com o golpe civil-militar de 1964, que depôs o presidente João Goulart em razão de seus projetos vanguardistas de reformas sociais (CUNHA JÚNIOR, 2015). São editados uma série de Atos Institucionais regulando o governo de transição e, em 1967, é promulgada pelo Congresso Nacional uma nova Carta Constitucional, que, embora mencionasse a proteção ao regime democrático, em seus artigos 148, 149, 151 e 166, muito se parecia com a Constituição do Estado Novo de Getúlio Vargas, pois ampliou as prerrogativas do poder executivo, com o argumento de resguardar a segurança nacional, bem como centralizou poderes na União (BRASIL, 1967).

A aparência democrática durou pouco, pois, em 1968, é editado o Ato Institucional $n^{\circ} 5$, o qual ampliou os poderes discricionários do Presidente da República e culminou no fechamento do Congresso Nacional, bem como na Emenda Constitucional nº 1/69, outorgada pela junta militar formada pelos Ministros da Marinha, da Guerra, do Exército e da Aeronáutica Militar, cujo caráter explicitamente repressivo a faz ser considerada, nos dias de hoje, como uma nova Constituição, pois ela verdadeiramente rompeu com a ordem constitucional anterior (CUNHA JÚNIOR, 2015).

O movimento pela redemocratização do país se intensificou e alcançou resultados, ao longo da década de 1980, primeiramente com a eleição dos Governadores de estado, em 1982, e depois com a eleição direta para Presidente da República, em 1985. Dela, saiu vitorioso Tancredo Neves, mas foi seu vice-presidente, José Sarney, quem assumiu o cargo, após o falecimento de Tancredo, ocorrido antes da posse. É, então, convocada uma Assembleia Nacional Constituinte, através da Emenda Constitucional $\mathrm{n}^{\circ} 26$, de 1985, composta por deputados e senadores eleitos pelo povo em 1986. Em 05 de outubro de 1988, é promulgada uma nova Constituição da República Federativa do Brasil (CUNHA JÚNIOR, 2015). 
A Constituição da República Federativa do Brasil, de forte cunho social e democrático, declara, em seu artigo $1^{\circ}$, constituir um Estado Democrático de Direito cujos fundamentos são a soberania, a cidadania, a dignidade da pessoa humana, os valores sociais do trabalho e da livre iniciativa, assim como o pluralismo político. Declara, ainda, que todo o poder emana do povo, que o exerce, seja através de representantes eleitos, seja de forma direta, nos termos da Constituição (BRASIL, 1988).

A Constituição Federal de 1988 garantiu aos cidadãos, em seu artigo 14, além do sufrágio universal, a possibilidade de participação direta no Estado, por meio de plebiscito, referendo e iniciativa popular de leis. No artigo $5^{\circ}$, LXXIII, previu a ação popular, legitimando o cidadão a pleitear judicialmente a anulação de atos lesivos ao patrimônio público e a direitos transindividuais. No artigo 29, também determinou que haja a cooperação das associações representativas no planejamento municipal, bem como previu a iniciativa popular de projetos de lei de interesse específico do município. Pelo artigo 225, impôs à coletividade, em conjunto com o poder público, o dever de defender e preservar o meio ambiente para as presentes e futuras gerações (BRASIL, 1988).

Devido ao trauma dos anos de repressão, a Constituição Federal de 1988 traz uma extensa declaração de direitos e garantias fundamentais. Em seu artigo $5^{\circ}$, ressalva a existência de outros direitos decorrentes dos princípios e do regime por ela adotados, bem como de tratados internacionais firmados pelo país. Ainda foram previstos remédios constitucionais para a proteção daqueles direitos, como o direito de petição, o habeas corpus, o habeas data, o mandado de segurança e o mandado de injunção.

Com isso, observa-se a adoção, pela Constituição de 1988, de um modelo de democracia, denominada de participativa, cuja soberania popular é exercida de diversas formas, sendo a representação política apenas uma delas. O modelo participativo de democracia demanda uma maior atuação dos setores sociais na gestão estatal, fazendo com que outros mecanismos de incremento da participação popular nas decisões do Estado sejam incorporados ao ordenamento jurídico. 
No poder legislativo brasileiro, a Câmara de Deputados e o Senado Federal instituíram portais de debate e consulta pública sobre temas em votação nas respectivas casas legislativas. O portal e-democracia, da Câmara dos Deputados, tem como proposta incentivar a participação da sociedade no debate de temas importantes do país, ao fundamento de que a participação cidadã na formulação das leis contribui para a adoção de políticas públicas mais condizentes com a realidade social. Já o portal e-cidadania, do Senado, visa fomentar a participação do cidadão em suas atividades legislativas, orçamentárias, fiscalizadoras e de representação, viabilizando a participação online do cidadão em audiências e consultas públicas, além da possibilidade de apoiar ou sugerir um projeto de lei (LENZA, 2016).

No poder executivo federal, foi promulgado, em 23 de maio de 2014, o decreto $n^{\circ} 8.243$, que instituiu a Política Nacional de Participação Social (PNPS), com o objetivo de fortalecer e articular os mecanismos e as instâncias democráticas de diálogo e a atuação conjunta entre a administração pública federal e a sociedade civil. A PNPS estabeleceu como objetivos consolidar a participação social como método de governo; promover a articulação das instâncias e dos mecanismos de participação social; aprimorar a relação do governo federal com a sociedade civil, respeitando a autonomia das partes; promover e consolidar a adoção de mecanismos de participação social nas políticas e programas de governo federal; desenvolver mecanismos de participação social nas etapas do ciclo de planejamento e orçamento; incentivar o uso e o desenvolvimento de metodologias que incorporem múltiplas formas de expressão e linguagens de participação social, por meio da internet, com a adoção de tecnologias livres de comunicação e informação, especialmente, softwares e aplicativos, tais como códigos-fonte livres e auditáveis, ou os disponíveis no Portal do Software Público Brasileiro; desenvolver mecanismos de participação social que sejam acessíveis aos grupos sociais historicamente excluídos e aos vulneráveis; incentivar e promover ações e programas de apoio institucional, formação e qualificação em participação social para agentes públicos e sociedade civil; e incentivar a participação social nos entes federados. O decreto $\mathrm{n}^{\circ}$ 
8.243 determinou, ainda, que os órgãos e as entidades da administração pública federal direta e indireta considerassem, na formulação, execução, monitoramento e avaliação de seus programas e políticas públicas, as instâncias e os mecanismos de participação social (BRASIL, 2014).

Já no poder executivo municipal, a tônica da participação popular reside na criação do orçamento participativo, implementado de forma experimental pelas cidades de Porto Alegre (RS) e Belo Horizonte (MG). A origem do orçamento participativo no âmbito local remonta tanto ao cumprimento da quantidade orçamentária, prevista no artigo 29 da Constituição de 1988, que assegura a participação social no planejamento, quanto à realidade social de fortalecimento das associações comunitárias e sua atuação junto ao poder público, sendo este um fator de cultura local (AVRITZER, 2002).

Quanto ao poder judiciário, vislumbrou-se uma crescente regulamentação no ordenamento jurídico brasileiro, a partir da década de 1990, de institutos simplificadores do processo, como ritos procedimentais próprios para causas de menor complexidade - microssistema dos juizados especiais, as leis 9.099/95, 10.259/01 e 12.153/09 - bem como métodos alternativos de solução de conflitos, como a lei da arbitragem e a lei da mediação, e até mesmo a disciplina do processo coletivo. Tal movimento de reforma do sistema processual decorreu tanto da necessidade de criação de mecanismos que desafogassem o poder judiciário à vista da crescente judicialização de conflitos, quanto da demanda por efetividade do direito de acesso à justiça, o que ocorreu sobremaneira após a instituição do Código de Defesa do Consumidor de 1990 (SOUZA, 2011).

O conceito de soberania popular e cidadania ativa foram alterados sensivelmente com a evolução da concepção em torno do princípio democrático - da democracia representativa do Estado liberal para a democracia participativa do Estado social. Paulo Bonavides (2001), entusiasta da democracia participativa enquanto único regime capaz de moralizar a gestão do Estado e realizar de forma eficaz o bem comum, reconhece na Constituição Federal de 1988 um fragmento normativo que propicia o desenvolvimento da democracia participativa. Para ele, o cidadão, nesse sistema, 
concentra o significado de povo, soberania, nação e governo, identificando-se cada vez menos com o regime representativo e cada vez mais com a democracia direta, de natureza legitimamente soberana e popular. A democracia participativa assumiria, segundo ele, um caráter patriótico e combativo num momento histórico em que a globalização e o neoliberalismo dissolvem os valores da sociedade democrática, soberana e constitucional e atuam no sentido da recolonização através do capital internacional (BONAVIDES, 2001).

\section{Os instrumentos de participação popular no governo Bolsonaro}

Atualmente, contudo, o Brasil vive um momento de instabilidade política, originada em múltiplos escândalos de corrupção no governo federal e agravada por uma crise econômica, tendo passado pelo impeachment da então presidenta da República, Dilma Rousseff, em 2016, bem como pela prisão de dois ex-presidentes, Luiz Inácio Lula da Silva e Michel Temer. No seio de tal crise, emergiu e se fortaleceu novamente o discurso autoritário no meio social, o que resultou na eleição, em 2018, do conservador e controverso ex-militar, Jair Messias Bolsonaro para Presidente da República.

Em 11 de abril de 2019, em comemoração aos 100 dias de seu governo, Bolsonaro assinou o decreto n 9.759/2019, por meio do qual determinou a extinção dos órgãos colegiados de participação popular na administração pública federal, como por exemplo o Conselho Nacional dos Direitos da Pessoa com Deficiência (CONADE), o Conselho Nacional de Erradicação do Trabalho Infantil (CONAETI), o Conselho Nacional dos Direitos do Idoso (CNDI), o Conselho Nacional de Transparência Pública e Combate à Corrupção (CTPCC), o Conselho Nacional de Segurança Pública (CONASP), além da Comissão Nacional da Política Indigenista (CNPI), da Comissão Nacional da Biodiversidade (Conabio) e do Comitê Gestor da Internet no Brasil (CGI) (ARAÚJO, 2019). O decreto $\mathrm{n}^{\circ} 9.759 / 2019$ também revogou o decreto $n^{\circ} 8.243 / 2014$, que 
instituía a Política Nacional de Participação Social (PNPS), cuja finalidade era o fortalecimento da participação democrática através da atuação conjunta entre a administração pública federal e a sociedade civil. Estima-se que a medida possa resultar na extinção de 700 órgãos colegiados consultivos de participação voluntária da sociedade civil, entre conselhos, comitês, comissões, grupos, juntas, equipes, mesas, fóruns, salas (VENTURA, 2019a).

Em maio de 2019, um novo decreto do presidente Jair Bolsonaro alterou e reduziu a composição do Conselho Nacional do Meio Ambiente (CONAMA). O colegiado, que contava com quase 100 titulares, passou a ser composto por 21 membros titulares, sendo presidido pelo ministro do Meio Ambiente (VENTURA, 2019b).

Em julho de 2019, mais um decreto presidencial retirou a participação da sociedade civil, dessa vez do Conselho Nacional de Políticas sobre Drogas, o CONAD. Anteriormente composto por 28 membros, entre representantes do governo federal, médicos, psicólogos, assistentes sociais, juristas e entidades civis especialistas no tema, agora o colegiado será composto apenas por integrantes do governo. O CONAD passará a ser composto pelo Ministro de Estado da Justiça e Segurança Pública, que o presidirá; o Ministro de Estado da Cidadania; um representante do Ministério da Defesa; um representante do Ministério das Relações Exteriores; um representante do Ministério da Economia; um representante do Ministério da Educação; um representante do Ministério da Saúde; um representante do Ministério da Mulher, da Família e dos Direitos Humanos; um representante do Gabinete de Segurança Institucional da Presidência da República; e um representante da Agência Nacional de Vigilância Sanitária (BLOWER, 2019).

Em combate à extinção dos conselhos consultivos federais de participação voluntária da sociedade civil pelo governo federal, o Partido dos Trabalhadores (PT) propôs a Ação Direta de Inconstitucionalidade (ADI) 6121 junto ao Supremo Tribunal Federal (STF). Em 13 de junho de 2019, por unanimidade, o STF deferiu o pedido de medida liminar para impedir que o presidente Jair Bolsonaro extinga, por decreto, os conselhos da administração federal que tenham amparo em lei. Contudo, a liminar não 
protege contra a extinção os conselhos que tenham sido instituídos por atos normativos infralegais, como decretos, portarias e resoluções. Trata-se de decisão provisória, estando pendente o julgamento definitivo da ADI (STF, 2019).

Conquanto seja papel majoritário do STF resguardar as normas e os valores constitucionais - dentre eles, a democracia participativa enquanto regime de governo - acima até mesmo de ações dos demais poderes, observa-se que a decisão liminar do STF foi no sentido de apenas resguardar os conselhos criados com respaldo em lei, deixando os demais órgãos colegiados federais de participação popular desprotegidos. Baseou-se, portanto, em uma possível inconstitucionalidade formal do decreto 9.759/2019, um vício de ordem formal, e não na violação dos ditames democráticos, ressalvados os votos vencidos dos Ministros Edson Fachin, Luís Roberto Barroso, Rosa Weber, Cármen Lúcia e Celso de Mello, que votaram para ampliar a proibição de extinção a todos os conselhos (BARBIÉRI; OLIVEIRA, 2019).

Assim, a atuação do presidente Bolsonaro no sentido de extinguir a maior parte dos órgãos federais de participação e deliberação popular pelo decreto 9.759/2019 e, ainda, de restringir ou excluir a participação da sociedade civil dos órgãos colegiados remanescentes reflete o descaso do atual governo com a participação popular e expõe a fragilidade de nossa democracia, pois esta, conquanto esteja - na teoria - prevista e resguardada na Constituição Federal de forma vanguardista, na prática corre o risco de ser relegada ao simbolismo pelo desuso.

Ao realizar uma delimitação conceitual profícua acerca do que seria a legislação simbólica para o Direito, Marcelo Neves (2018), citando Kindermann, apresenta três possíveis funções para a legislação simbólica: servir para confirmar valores sociais, demonstrar a capacidade de ação do Estado, bem como adiar a solução de conflitos sociais mediante compromissos dilatórios.

No que concerne ao uso da legislação simbólica com o objetivo de fortalecer a confiança dos cidadãos no governo ou no próprio Estado - a chamada legislação-álibi -, a finalidade primordial da norma passa a ser inspirar confiança nos sistemas políticos e 
jurídicos, consistindo em uma demonstração das boas intenções do Estado, de modo a aliviá-lo de pressões políticas ou mostrar sua sensibilidade frente às demandas do povo. Desse modo, a legislação-álibi, além de realmente não resolver as questões sociais que urgem por atenção, acaba por mascarar o problema, dificultando a promoção do debate e da solução (NEVES, 2018).

Sob a perspectiva da teoria dos sistemas sociais de Niklas Luhmann, uma sociedade equilibrada mantém seus sistemas sociais - Direito, Economia, Política, Família, Religião, Arte - em constante diálogo, porém independentes em suas respectivas lógicas existenciais - sistemas autopoiéticos, ressalvando-se que a Constituição funciona como um acoplamento estrutural dos sistemas jurídico e político de uma sociedade. Contudo, havendo a colonização de um sistema por outro, há uma desnaturação sistêmica, passando um campo social a funcionar pela lógica de outro - sistemas alopoiéticos (NEVES, 2018). Nesse sentido, a constitucionalização simbólica consistiria na colonização do Direito pela Política, fazendo com que o sistema jurídico constitucional passasse a se desenvolver sob a lógica do poder e não da licitude. O resultado seria a deterioração dos instrumentos constitucionais de controle político, para que o discurso constitucional fosse utilizado como retórica estratégica para angariar a lealdade das massas, de acordo com a conveniência de minorias privilegiadas ou, em última instância, de regimes autoritários (NEVES, 2018).

Isso se trataria do que Paulo Bonavides (2001) intitula de golpe de Estado institucional, contraposto ao golpe de Estado governamental, porque não remove governos, mas dissolve regimes. De forma silenciosa e clandestina - pois o discurso governamental mascara sua real agenda -, a elite detentora do poder político e econômico agiria através da deturpação de valores, do estabelecimento de privilégios não previstos na Constituição, por meio de normas precárias, e da atuação em benefício do capital internacional, conduzindo os países periféricos à perda total da identidade nacional e à redução de seu status ao de neocolônias (BONAVIDES, 2001).

Também Bonavides (2001), ao criticar a influência do neoliberalismo no Brasil do final da década de 1990, já alertava para a perda de eficácia social dos fundamentos e objetivos da República, 
previstos nos artigos $1^{\circ}$ e $3^{\circ}$ da Constituição Federal de 1988. Ele chegou a acusar o governo de se alinhar ao poder econômico em detrimento da sociedade, desprezando paulatina e silenciosamente as normas supremas em prol da agenda da globalização, transformando os princípios fundamentais em mero pedaço de papel, "um texto de poesia constitucional" (BONAVIDES, 2001, p. 185).

Como ressalta o próprio Marcelo Neves (2018), em sua análise acerca da constitucionalização simbólica, é preciso ressalvar que o poder estatal, no uso de institutos constitucionais como álibi e discurso estratégico, também encontra limites, pois, quando tal recurso é muito utilizado sem que haja algum grau de satisfação pelas demais instâncias sociais das demandas latentes, ocorre a perda de credibilidade do Estado e de suas instituições aos olhos do povo. Assim, a mera previsão do regime democrático na Constituição Federal de 1988 não é suficiente para sustentar a manutenção da democracia no Brasil, quando medidas de restrição à participação popular são reiteradamente adotadas pelo governo, sob pena de se incorrer em discurso retórico vazio e insustentável, o qual desaguará na perda da confiança no Estado e em suas instituições.

É válido acrescentar que Bonavides (2001) acreditava no restabelecimento do equilíbrio entre os sistemas político e jurídico no seio constitucional, através do fortalecimento da democracia participativa, resultando numa simbiose de princípios, regras e valores que conformam a Constituição, a qual seria guiada pela nova hermenêutica constitucional e teria por intérprete um tribunal constitucional integrado por membros eleitos pelo povo.

\section{Conclusão}

De tudo isso, se conclui o risco de termos, na realidade política brasileira, uma democracia que caminha para o simbolismo e o campo do discurso estratégico, tornando-se álibi constitucional dos dirigentes do Estado, que, com o apoio da mídia, domina a opinião pública e sufoca o debate acerca da eficácia dos mecanismos garantidores do ideal democrático. 
A apatia popular já foi utilizada como premissa para uma teoria elitista de defesa da democracia representativa, segundo a qual o povo não possui capacidade ou interesse suficientes para interferir diretamente nas instâncias de poder. Essa seria a razão pela qual deveria ser delegada a uma minoria privilegiada e esclarecida a prerrogativa de disputar o poder político através da eleição, competindo ao povo o diminuto papel de votar no candidato que entender mais capacitado. Esse mito não tem mais lugar nos dias de hoje, sobretudo quando a era digital revolucionou o acesso à informação e às formas de participação do cidadão nos poderes estatais. Hoje, ao povo tudo é dado conhecer e em tudo é possibilitada a sua participação, permitindo os meios digitais, inclusive, que a participação popular ocorra sem a oneração do erário.

Desse modo, não há razão para se tolerar o retrocesso da democracia à mera representatividade eleitoral, somente porque o discurso governamental e a mídia sustentam que a Constituição está sendo respeitada. Vigência não quer dizer, necessariamente, aplicação das normas constitucionais. A história política brasileira evidencia as inúmeras alternâncias entre períodos de avanços democráticos e períodos de retrocesso ao autoritarismo, o que nos ensina, enquanto povo brasileiro, a não descuidarmos de defender a titularidade e posse de nossa soberania.

É preciso, portanto, que se faça a constante análise da existência, validade e eficácia social do regime democrático garantido constitucionalmente. Além disso, faz-se necessária a avaliação crítica do discurso governamental e midiático, para que, através do constante questionamento, se possa tomar ciência dos ataques ao regime democrático, nesses tempos de crise moral, econômica e política. Por fim, é fundamental que o povo, tomando consciência de que nele reside a soberania do Estado, busque sempre caminhos para validar a democracia, através de sua participação ativa na condução dos poderes estatais. 


\section{REFERÊNCIAS}

ARAUJO, G. S. S. de. Extinção de conselhos reflete descaso do governo com a democracia. Consultor Jurídico, [on line], abr. 2019. Disponível em: <https://www.conjur.com.br/2019-abr-30/gabriela-araujo-extincaoconselhos-reflete-descaso-democracia>. Acesso em: 08 jun. 2019.

AVRITZER, L. Modelos de deliberação democrática: uma análise do orçamento participativo no Brasil. In: SANTOS, B. de S. (org.). Democratizar a democracia. Rio de Janeiro. Civilização Brasileira, 2002. p. $561-598$.

BARBIÉRI, L. F.; OLIVEIRA, M. STF impede Bolsonaro de extinguir via decreto conselhos federais criados por lei. O Globo, Brasília, 13 jun. 2019. Disponível em: <https://g1.globo.com/politica/noticia/2019/06/13/stfconclui-julgamento-e-impede-bolsonaro-de-fechar-conselhos-federaiscriados-por-lei.ghtml>. Acesso em: 01 ago. 2019.

BLOWER, A. P. Bolsonaro reduz participação da sociedade civil no Conselho Nacional de Políticas sobre Drogas. O Globo, Brasília, 22 jul. 2019. Disponível em: <https://oglobo.globo.com/sociedade/bolsonaroreduz-participacao-da-sociedade-civil-no-conselho-nacional-de-politicassobre-drogas-23823514>. Acesso em: 01 ago. 2019.

BOBBIO, N. Estado, governo e sociedade: para uma teoria geral da política. 2. ed. Rio de Janeiro: Paz e Terra, 1987.

BONAVIDES, P. Ciência política. 10. ed. São Paulo: Malheiros, 2000.

Teoria constitucional da democracia participativa: por um direito constitucional de luta e resistência, por uma nova hermenêutica, por uma repolitização da legitimidade. São Paulo: Malheiros, 2001.

BRASIL. Constituição dos Estados Unidos do Brasil (1891). Rio de Janeiro, 1891. Disponível em: <http://www.planalto.gov.br/ccivil_03/ constituicao/constituicao91.htm>. Acesso em: 10 jun. 2019.

Constituição dos Estados Unidos do Brasil (1937). Rio de Janeiro, 1937. Disponível em: <http://www.planalto.gov.br/ccivil_03/ Constituicao/Constituicao37.htm>. Acesso em: 10 jun. 2019.

Constituição dos Estados Unidos do Brasil (1946). Rio de Janeiro, 1946. Disponível em: <http://www.planalto.gov.br/ccivil_03/ constituicao/constituicao46.htm>. Acesso em: 10 jun. 2019.

Constituição da República Federativa do Brasil de 1967.

Brasília, 1967. Disponível em: <http://www.planalto.gov.br/ccivil_03/ constituicao/constituicao67.htm>. Acesso em: 10 jun. 2019. 
Constituição da República Federativa do Brasil de 1988.

Brasília, 1988. Disponível em: <http://www.planalto.gov.br/ccivil_03/ constituicao/constituicao.htm>. Acesso em: 10 jun. 2019.

Decreto $\mathrm{n}^{\circ} \mathbf{8 . 2 4 3}$, de 23 de maio de 2014 . Revogado pelo Decreto ${ }^{\circ}$ 9.759, de 2019. Institui a Política Nacional de Participação Social (PNPS) e o Sistema Nacional de Participação Social (SNPS) e dá outras providências. Brasília, 2014. Disponível em: <http://www.planalto.gov.br/ ccivil_03/_ato2011-2014/2014/decreto/d8243.htm>. Acesso em: 10 jul. 2019.

CABRAL NETO, A. Democracia: velhas e novas controvérsias. Estudos de Psicologia, São Paulo, v. 2, n. 2, p. 287 - 312, 1997.

COMPARATO, F. K. A nova cidadania. Lua Nova: Revista de Cultura e Política, São Paulo, n. 28 - 29, p. 85 - 106, 1993.

CUNHA JR, D. da. Curso de Direito Constitucional. 9. ed. Salvador: JUSPODIVM, 2015.

HUNTINGTON, S. A terceira onda: a democratização no final do século XX. São Paulo: Ática, 1994.

LENZA, P. Direito constitucional esquematizado. 20. ed. São Paulo: Saraiva, 2016.

NEVES, M. A constitucionalização simbólica. 3. ed. São Paulo: WMF Martins Fontes, 2018.

SANTOS, B. de S. Reinventar a democracia. 2. ed. Lisboa: Gradiva, 2002a.

Para ampliar o cânone democrático. In: . (org.). Democratizar a democracia: os caminhos da democracia participativa. Rio de Janeiro: Civilização Brasileira, 2002b. p. 39 - 82.

SILVA, J. A. da. Acesso à justiça e cidadania. Revista de Direito Administrativo, Rio de Janeiro, n. 216, p. 09 - 23, 1999.

SOUZA, W. A. de. Acesso à justiça. Salvador: Dois de Julho, 2011.

STF - Superior Tribunal Federal. Partido questiona decreto presidencial que extingue conselhos da administração pública. Notícias STF, Brasília, 29 abr. 2019. Disponível em: <http://www.stf.jus.br/portal/cms/ verNoticiaDetalhe .asp?idConteudo=409787 >. Acesso em: 01 ag. 2019.

TOSI, M. Mulheres e Democracia. Politize!, [on line], 18 ago. 2016. Disponível em: <https://www.politize.com.br/conquista-do-direito-aovoto-feminino/>. Acesso em: 16 jun. 2019. 
VENTURA, L. A. S. Decreto de Bolsonaro acaba com o Conade e mais 700 conselhos. Estadão, São Paulo, 12 abr. 2019 (2019a). Blog Vencer Limites. Disponível em: <https://brasil.estadao.com.br/blogs/vencer-limites/ decreto-de-bolsonaro-acaba-com-o-conade-e-mais-700-conselhos/>. Acesso em: 15 abr. 2019.

VENTURA, M. Decreto de Bolsonaro reduz e altera composição do Conselho Nacional do Meio Ambiente. O Globo, Brasília, 29 mai. 2019 (2019b). Disponível em: <https://oglobo.globo.com/sociedade/decretode-bolsonaro-reduz-altera-composicao-do-conselho-nacional-do-meioambiente-23702598>. Acesso em: 01 ago. 2019. 